\title{
Random Amplified Polymorphic DNA Fingerprinting of Mosquito-Pathogenic and Nonpathogenic Strains of Bacillus sphaericus
}

\author{
MARY ALICE WOODBURN, ALLAN A. YOUSTEN, ${ }^{*}$ AND KHIDIR H. HILU \\ Microbiology and Immunology Section, Biology Department, Virginia Polytechnic Institute \\ and State University, Blacksburg, Vinginia 24061
}

\begin{abstract}
Random amplified polymorphic DNA fingerprinting was used to examine 31 mosquito-pathogenic and 14 nonpathogenic strains of Bacillus sphaericus. We verified that DNA bands that migrated the same distance in an agarose gel were homologous by using PCR-generated probes made from the random amplified polymorphic DNA bands. The band patterns obtained with eight primers were analyzed by using the Jaccard coefficient and unweighted pair group with arithmetic average clustering. Pathogenic strains belonging to DNA homology group IIA were similar to strains belonging to nonpathogenic homology groups at an average level of similarity of $6.3 \%$. Individual serotypes were clearly identified among the pathogenic strains. This suggests that there is overall genetic homogeneity among strains within serotypes. It is also consistent with the uniform toxicity pattern found for each serotype (unlike the toxin diversity found in Bacillus thuringiensis serotypes). These results, together with DNA homology data, support the proposal that a new species should be described for the pathogenic strains.
\end{abstract}

Mesophilic, strictly aerobic, spore-forming bacilli that are capable of producing spherical endospores have been designated Bacillus sphaericus. These bacteria metabolize a variety of organic and amino acids but cannot metabolize sugars, leading to negative results for many of the traditional phenotypic tests used in the classification of members of the genus Bacillus (6). The diversity of these bacteria was demonstrated by Krych et al. (14), who identified five distinct DNA homology groups among the 50 strains which they examined. Seven strains belonging to DNA homology group IIA are of particular interest as they are pathogenic for the larvae of certain species of mosquitoes. No mosquito pathogens were found among the other four homology groups.

Since this DNA homology study was published in 1980, more than 100 mosquito-pathogenic strains of $B$. sphaericus have been isolated worldwide. Highly toxic strains (with $50 \%$ lethal concentrations in the nanogram per milliliter range) are capable of producing binary toxin-containing paraspores during sporulation (19). Weakly toxic strains (with $50 \%$ lethal concentrations in the microgram per milliliter range) produce a $100-\mathrm{kDa}$, cell-bound toxin during vegetative growth (19). Both highly toxic strains and weakly toxic strains were found in DNA homology group IIA (14).

The creation of a separate species for the mosquito pathogens has been contemplated; however, the lack of positive phenotypic tests, other than mosquito pathogenicity, has delayed the description of such a taxon $(1,2,6,14)$. The situation is complicated by the existence of homology group IIB, a group of nonpathogenic strains that exhibit 60 to $66 \%$ homology with the group IIA reference strain. The stability of hybrid duplexes between strains belonging to these two groups was significantly less than the stability of homologous duplexes $(13,14)$; the data correspond to a level of mismatches between group IIA and IIB strains of 4 to $5 \%$ and reinforce the distinctness of the groups. In a study of $91 \mathrm{~B}$. sphaericus strains in which 155 phenotypic tests were used, strains belonging to homology

* Corresponding author. Phone: (703) 231-5909 or (703) 231-8938. Fax: (703) 231-9307. group IIA clustered with strains belonging to homology group IIB at a Jaccard similarity level of $85.5 \%$ (1). The major distinguishing characteristic was the ability of group IIA strains to clear adenine from nutrient agar (1). The results of a numerical analysis of phenotypic features (20), a cellular fatty acid analysis (12), a ribotyping analysis (2), and an rRNA sequence analysis (3) support the DNA homology data.

Pathogenic strains have also been classified by serotyping and bacteriophage typing. Highly toxic strains that produce binary toxins are found in serotypes $5 \mathrm{a} 5 \mathrm{~b}, 6,25$, and 48 , as well as in phage types 3 and $4(9,24)$. The strains that produce only the $100-\mathrm{kDa}$ toxin belong to serotypes $1 \mathrm{a}$ and $2 \mathrm{a} 2 \mathrm{~b}$ and phage types 1 and $2(9,24)$.

Random amplified polymorphic DNA (RAPD) fingerprinting has been used to differentiate several related species and strains of bacteria, including another insect pathogen, Bacillus thuringiensis $(7,22)$. In this method short oligonucleotide primers of an arbitrary sequence are used to amplify DNA regions by PCR. The RAPD method is particularly useful because previous sequence information is not necessary (23).

Because pathogenic strains of $B$. sphaericus are currently being examined for commercial applications, workers need to decide whether there is sufficient evidence to classify these strains in a separate species. In this study, 31 pathogenic and 14 nonpathogenic strains of $B$. sphaericus were examined by the RAPD method to determine their genetic relationships.

\section{MATERIALS AND METHODS}

Bacterial strains and growth conditions. The bacteria used in this study are listed in Table 1 . Portions $(5 \mathrm{ml})$ obtained from overnight shaken tubes containing NY broth (Difco nutrient broth supplemented with $0.05 \%$ [wt/vol] yeast extract) were transferred to $150-\mathrm{ml}$ portions of NY broth in 500-ml Erlenmeyer flasks and shaken at $150 \mathrm{rpm}$ at $30^{\circ} \mathrm{C}$ for $10 \mathrm{~h}$.

DNA isolation. DNA was isolated by a modification of a method of Burke (7a) Cells from 150-ml NY broth cultures were resuspended in $7.5 \mathrm{ml}$ of $10 \mathrm{mM}$ Tris-Cl (pH 8.0)-1 mM EDTA (TE) containing $1 \mathrm{mg}$ of lysozyme (Sigma) per ml and incubated at $37^{\circ} \mathrm{C}$ until the solution became viscous. Then $0.5 \mathrm{ml}$ of a $10 \%$ sodium dodecyl sulfate (SDS) solution and $1.0 \mathrm{mg}$ of proteinase K (Sigma) were added, and the preparation was mixed and incubated for $2 \mathrm{~h}$ at $50^{\circ} \mathrm{C}$. An $8-\mathrm{ml}$ portion of phenol-chloroform-isoamyl alcohol $(25: 24: 1)$ was added, and the preparation was mixed and centrifuged. The aqueous layer was transferred to a new tube, $0.6 \%$ (vol/vol) isopropanol was added, and the DNA was spooled onto a 
TABLE 1. Strains of $B$. sphaericus used in this study

\begin{tabular}{|c|c|c|c|}
\hline Strain & Serotype & Source & Origin \\
\hline Kellen K & 1 & S. Singer & Fresno, Calif. \\
\hline Kellen Q & 1 & S. Singer & Derived from Kellen $\mathrm{K}$ \\
\hline SSII-1 & 2 & S. Singer & India \\
\hline 1404 & 2 & S. Singer & The Philippines \\
\hline 1883 & 2 & S. Singer & Israel \\
\hline 1593 & $5 \mathrm{a} 5 \mathrm{~b}$ & S. Singer & Indonesia \\
\hline 2362 & $5 \mathrm{a} 5 \mathrm{~b}$ & J. Weiser & Nigeria \\
\hline 1691 & $5 \mathrm{a} 5 \mathrm{~b}$ & S. Singer & El Salvador \\
\hline 1881 & $5 \mathrm{a} 5 \mathrm{~b}$ & S. Singer & El Salvador \\
\hline 2500 & $5 \mathrm{a} 5 \mathrm{~b}$ & S. Singer & Thailand \\
\hline S2 & $5 a 5 b$ & P. Vilarinhos & Brazil \\
\hline TG 148 & $5 \mathrm{a} 5 \mathrm{~b}$ & T. Guaycurus & Brazil \\
\hline JI 21 & $5 \mathrm{a} 5 \mathrm{~b}$ & J. Ibarra & Mexico \\
\hline JI 42 & $5 \mathrm{a} 5 \mathrm{~b}$ & J. Ibarra & Mexico \\
\hline JI 167 & $5 \mathrm{a} 5 \mathrm{~b}$ & J. Ibarra & Mexico \\
\hline IAB 59 & 6 & J. Ofori & Ghana \\
\hline IAB 611 & 6 & J. Ofori & Ghana \\
\hline IAB 763 & 6 & J. Ofori & Ghana \\
\hline IAB 769.1 & 6 & J. Ofori & Ghana \\
\hline IAB 872 & 48 & J. Ofori & Ghana \\
\hline 2297 & 25 & R. Wickremsinghe & Sri Lanka \\
\hline TG 365 & 25 & T. Guaycurus & Brazil \\
\hline TG 393 & 25 & T. Guaycurus & Brazil \\
\hline LP 7A & $\mathrm{NT}^{a}$ & F. Priest & Singapore \\
\hline LP 20E & NT & F. Priest & Singapore \\
\hline LP 1G & NT & F. Priest & Singapore \\
\hline LP 12AS & NT & F. Priest & Singapore \\
\hline LP 14-8 & NT & F. Priest & Singapore \\
\hline LP 35-6 & NT & F. Priest & Singapore \\
\hline LP 24-4 & NT & F. Priest & Singapore \\
\hline 2173 & 26 & S. Amonkar & India \\
\hline $31-2$ & 9 & C. Cokmus & Turkey \\
\hline ATCC $14577^{\mathrm{T} b}$ & NT & S. Singer & \\
\hline NRS 967 & NT & R. Gordon & \\
\hline NCTC 9602 & NT & D. Tipper & \\
\hline NRS 718 & NT & R. Gordon & \\
\hline ATCC 7055 & NT & R. Gordon & \\
\hline NRS 1191 & NT & R. Gordon & \\
\hline ATCC 12300 & NT & R. Gordon & \\
\hline NRS 592 & NT & R. Gordon & \\
\hline ATCC 12123 & NT & R. Gordon & \\
\hline P1 & NT & D. Tipper & \\
\hline NRS 400 & NT & R. Gordon & \\
\hline ATCC 13805 & NT & R. Gordon & \\
\hline NRS 1198 & NT & R. Gordon & \\
\hline NRS 1199 & NT & R. Gordon & \\
\hline
\end{tabular}

\section{${ }^{a}$ NT, not typed.}

${ }^{b} \mathrm{~T}=$ type strain.

sterile glass hook to dry. The DNA was resuspended in TE, the DNA concentration was determined with a model TKO 100 minifluorometer (Hoefer Scientific), and $5-\mathrm{ng} / \mu \mathrm{l}$ dilutions were prepared for RAPD experiments.

RAPD analysis. Primers were obtained from Operon Technologies, Inc., and were resuspended in sterile, filtered water to a concentration of $0.125 \mu \mathrm{g} / \mu \mathrm{l}$. A total of 30 primers were screened, and 8 were chosen because they provided informative band patterns. The nucleotide sequences of these primers are shown in Table 2.

The following reagents were added to each $25-\mu l$ reaction mixture, which was overlaid with $20 \mu \mathrm{l}$ of mineral oil: $2.5 \mu \mathrm{l}$ of $10 \times$ Promega buffer $(500 \mathrm{mM} \mathrm{KCl}$, $100 \mathrm{mM}$ Tris- $\mathrm{HCl}[\mathrm{pH} 9.0], 1.0 \%$ Triton X-100), $1 \%$ (vol/vol) glycerol, each deoxynucleoside triphosphate (dNTP) at a concentration of $100 \mu \mathrm{M}, 3 \mathrm{mM}$ $\mathrm{MgCl}_{2}, 0.6 \mu \mathrm{M}$ primer, $1.5 \mathrm{U}$ of $\mathrm{Ta} q$ polymerase (Promega), $15 \mathrm{ng}$ of DNA template, and enough sterile water to bring the total volume to $25 \mu$ l. Control reaction mixtures lacking template DNA were also prepared. RAPD experiments were performed with each primer at least twice. All amplification reactions were performed in a model PTC-100 thermocycler (MJ Research). The temperature profile was as follows: initial denaturation at $95^{\circ} \mathrm{C}$ for $5 \mathrm{~min}$ followed by 75 cycles consisting of $94^{\circ} \mathrm{C}$ for $20 \mathrm{~s}, 36^{\circ} \mathrm{C}$ for $20 \mathrm{~s}$, and $72^{\circ} \mathrm{C}$ for $2 \mathrm{~min}$.

Following amplification, $12 \mu \mathrm{l}$ of product was electrophoresed in a $1.7 \%$ gel containing 1.0\% (wt/vol) Synergel (Diversified Biotech) and 0.7\% (wt/vol) aga-
TABLE 2. Nucleotide sequences of primers used for RAPD analysis

Primer
OPA-7
OPA-11
OPA-17
OPA-18

rose (International Biotechnologies, Inc.) in TAE buffer ( $40 \mathrm{mM}$ Tris-acetate, 1 mM EDTA; pH 8.0). The gel was electrophoresed at $3.2 \mathrm{~V} / \mathrm{cm}$ in TAE buffer, stained in a solution containing $0.5 \mu \mathrm{g}$ of ethidium bromide per $\mu \mathrm{l}$, and photographed in UV light.

Probe synthesis. A single RAPD band was isolated from a 1.7\% low-meltingpoint agarose gel (Fisher) and was purified by using a Wizard PCR Preps kit (Promega). The isolated band was labeled by PCR, using digoxigenin-11-dUTP (Boehringer Mannheim) and a modification of previously described methods $(11,15)$. A $10 \times$ concentrated digoxigenin-dNTP labeling mixture $(1 \mathrm{mM}$ dATP, $1 \mathrm{mM}$ dCTP, $1 \mathrm{mM}$ dGTP, $0.65 \mathrm{mM}$ dTTP, $0.35 \mathrm{mM}$ digoxigenin-dUTP; Boehringer Mannheim) was used in the reaction mixture. The following reagents were added to the $25-\mu$ l reaction mixture, which was overlaid with $20 \mu$ l of mineral oil: $2.5 \mu \mathrm{l}$ of $10 \times$ Promega buffer, $1 \%$ glycerol, $100 \mu \mathrm{M}$ digoxigenin-dNTPs, $3 \mathrm{mM}$ $\mathrm{MgCl}_{2}, 2.0 \mu \mathrm{M}$ primer, $2.0 \mathrm{U}$ of Taq polymerase (Promega), $1 \mu \mathrm{l}$ of DNA template, and enough sterile water to bring the total volume to $25 \mu \mathrm{l}$. The temperature profile was as follows: initial denaturation at $95^{\circ} \mathrm{C}$ for $5 \mathrm{~min}$ followed by 30 cycles consisting of $94^{\circ} \mathrm{C}$ for $30 \mathrm{~s}, 36^{\circ} \mathrm{C}$ for $30 \mathrm{~s}$, and $72^{\circ} \mathrm{C}$ for $2 \mathrm{~min}$. The PCR product was removed and purified by using the Wizard PCR Preps kit.

To obtain a digoxigenin-dUTP-labeled probe for hybridization with the total RAPD products, RAPD reaction mixtures (see above) were prepared by using digoxigenin-dNTPs.

Southern transfer and DNA hybridization. DNA that was to be transferred was electrophoresed, stained, and photographed as described above. The DNA was transferred with a model 785 vacuum blotter (Bio-Rad) to a positively charged nylon membrane (Boehringer Mannheim) in 10× SSC (1× SSC is 0.15 $\mathrm{M} \mathrm{NaCl}$ plus $0.015 \mathrm{M}$ sodium citrate, $\mathrm{pH} 7.5$ ) for $1 \mathrm{~h}$ at 5 in $(\mathrm{ca} .12 .7 \mathrm{~cm}$ ) of mercury. The membrane was UV cross-linked (model FB UVXL-1000 apparatus; Fisher) and was placed in a heat-sealable bag with $20 \mathrm{ml}$ of standard prehybridization buffer (Boehringer Mannheim) per $100 \mathrm{~cm}^{2}$ and incubated for $2 \mathrm{~h}$ in a $65^{\circ} \mathrm{C}$ water bath.

The probe was boiled for $10 \mathrm{~min}, 5 \mathrm{ng}$ of probe per $100 \mathrm{~cm}^{2}$ of membrane was added, and the preparation was incubated overnight at $65^{\circ} \mathrm{C}$. The membrane was washed in $2 \times$ wash solution ( $2 \times$ SSC containing $0.1 \%$ SDS $)$ at room temperature for $5 \mathrm{~min}$ twice and then for $10 \mathrm{~min}$ and then was washed once in $0.5 \times$ wash solution $(0.5 \times \mathrm{SSC}$ containing $0.1 \% \mathrm{SDS})$ at $68^{\circ} \mathrm{C}$ for $1 \mathrm{~h}$. Color was developed as described by Boehringer Mannheim.

RAPD band analysis. The presence of RAPD bands in the 45 strains which we studied was determined for each primer. The data were treated as discrete, bistate characteristics. The data obtained with all eight primers were combined in one rectangular matrix, which was analyzed by using the Jaccard similarity coefficient algorithm. The matrix of coefficients which we generated was subjected to clustering by the unweighted pair group method with arithmetic averages (UPGMA). The cophenetic coefficients for the clusters were computed, and the correlation between these coefficients and the similarity matrix data was computed by using normalized Mantel statistics z (21). The NTSYS-pc computer program (version 1.8) was used in the analysis of the data (21).

\section{RESULTS}

RAPD fingerprinting. Template DNAs from 31 pathogenic and 14 nonpathogenic strains of $B$. sphaericus were used with eight decamer primers to generate DNA fragments by PCR. Controls lacking template DNA did not produce bands. In preliminary experiments, we found that the band patterns depended on the concentration of the primer, the template DNA, and $\mathrm{MgCl}_{2}$, in agreement with previously published data $(10$, $16,18)$. Variations in the intensities of the amplified segments did occur in repeated experiments performed with the same DNA preparations, but the band patterns were consistent when the same conditions were used. All band patterns analyzed in this study resulted from amplification under the set of conditions described in Materials and Methods. 


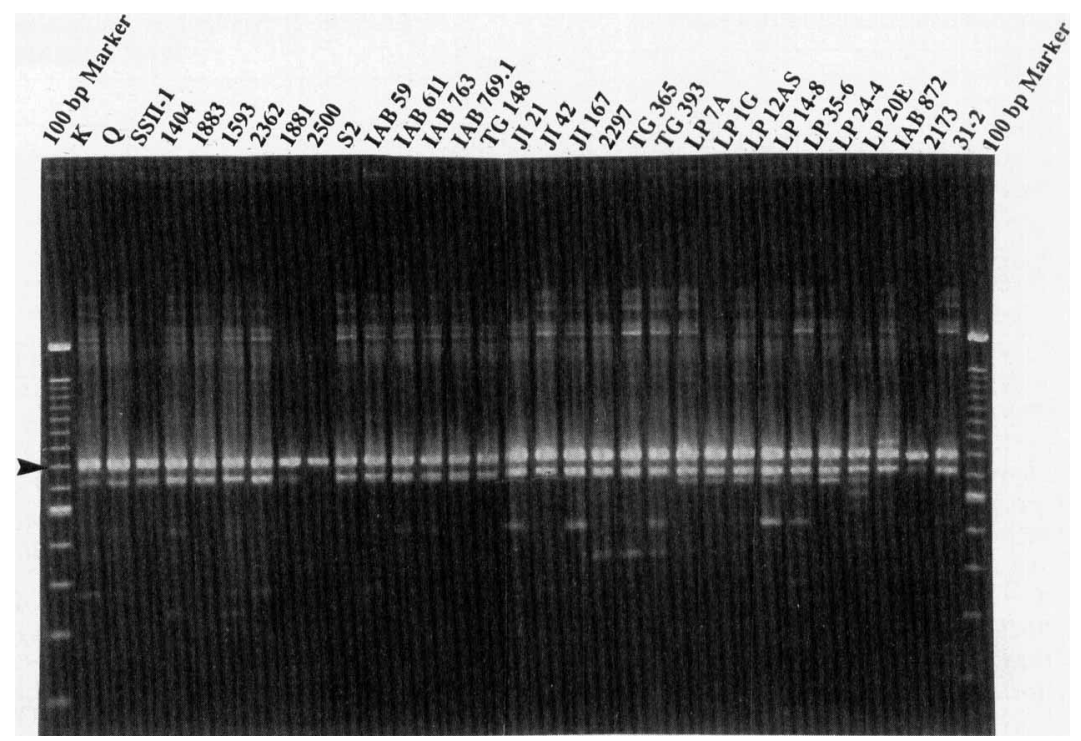

FIG. 1. RAPD band patterns generated by using primer OPA-17 and template DNAs from homology group IIA pathogenic strains. 100 bp Marker, DNA ladder (Gibco BRL) with 100-bp increments (the arrowhead indicates the band at $800 \mathrm{bp}$ ).

The clustering analysis revealed six groups that were separated at a similarity level of 0.055 . These groups corresponded to the DNA homology groups. Each of the DNA homology groups could be identified by distinctive band patterns. Figure 1 shows the pattern obtained for pathogenic strains belonging to homology group IIA produced with primer OPA-17. The prominent band at approximately $800 \mathrm{bp}$ was unique to this group of strains, and the patterns obtained for all of the pathogens examined were quite similar. These patterns can be compared with the patterns in Fig. 2, which were produced by using the same primer and template DNAs from strains belonging to homology groups I, IIB, III, IV, and V. Within a homology group, a rather uniform band pattern could be produced by one primer, while a variable pattern could be generated by a second primer. For example, Figure 3 shows the patterns resulting from the use of primer OPA-7 with template DNAs from pathogenic strains belonging to DNA homology group IIA. There was variation between strains, and the patterns produced paralleled the serotypes previously identified among the pathogens. In some cases serotype-specific bands could be recognized. When primer OPA-7 was used (Fig. 3), serotype 1 strains produced a unique band at approximately $1,150 \mathrm{bp}$. Strains of serotypes $5 \mathrm{a} 5 \mathrm{~b}$ and 25 produced two common bands at approximately 1,200 and $1,250 \mathrm{bp}$. Strains of serotypes 2 and 6 produced a band at $1,400 \mathrm{bp}$, and serotype 2 strains and the LP strains produced a band at $600 \mathrm{bp}$.

DNA hybridization. In order to verify that bands that migrated the same distance in agarose gels were homologous, probes were constructed by using RAPD products. A single DNA fragment that was approximately 725 bp long which was obtained from a RAPD reaction in which strain 1593 and primer OPB-18 were used was purified from agarose and hybridized with RAPD products obtained from four other strains (Fig. 4). Hybridization occurred only with the comigrating bands with each of the RAPD products tested. Hybridization did not occur with any band which migrated to another position in any of the four strains.

Although it was not practical to determine homology for each band produced with every primer, we labeled all of the products in a single RAPD reaction mixture with strain 1593 as amplification occurred and used these products to probe other RAPD products. In this experiment hybridization occurred only with those bands which migrated the same distances as the reference strain bands and not with other bands (data not shown).

Because plasmids are present in many strains of $B$. sphaericus, it was possible that amplification would occur from these plasmids and contribute bands to the RAPD fingerprints. A probe made from an entire RAPD product by using primer
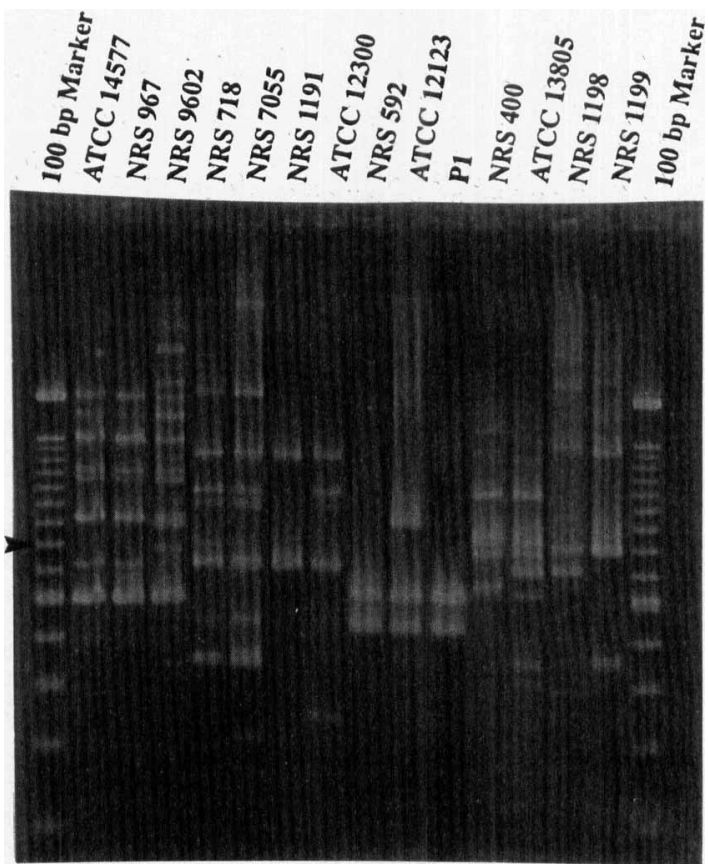

FIG. 2. RAPD band patterns generated by using primer OPA-17 and template DNAs from homology group I, IIB, III, IV, and V strains. 100 bp Marker, DNA ladder with 100 -bp increments (the arrowhead indicates the band at 800 bp). 


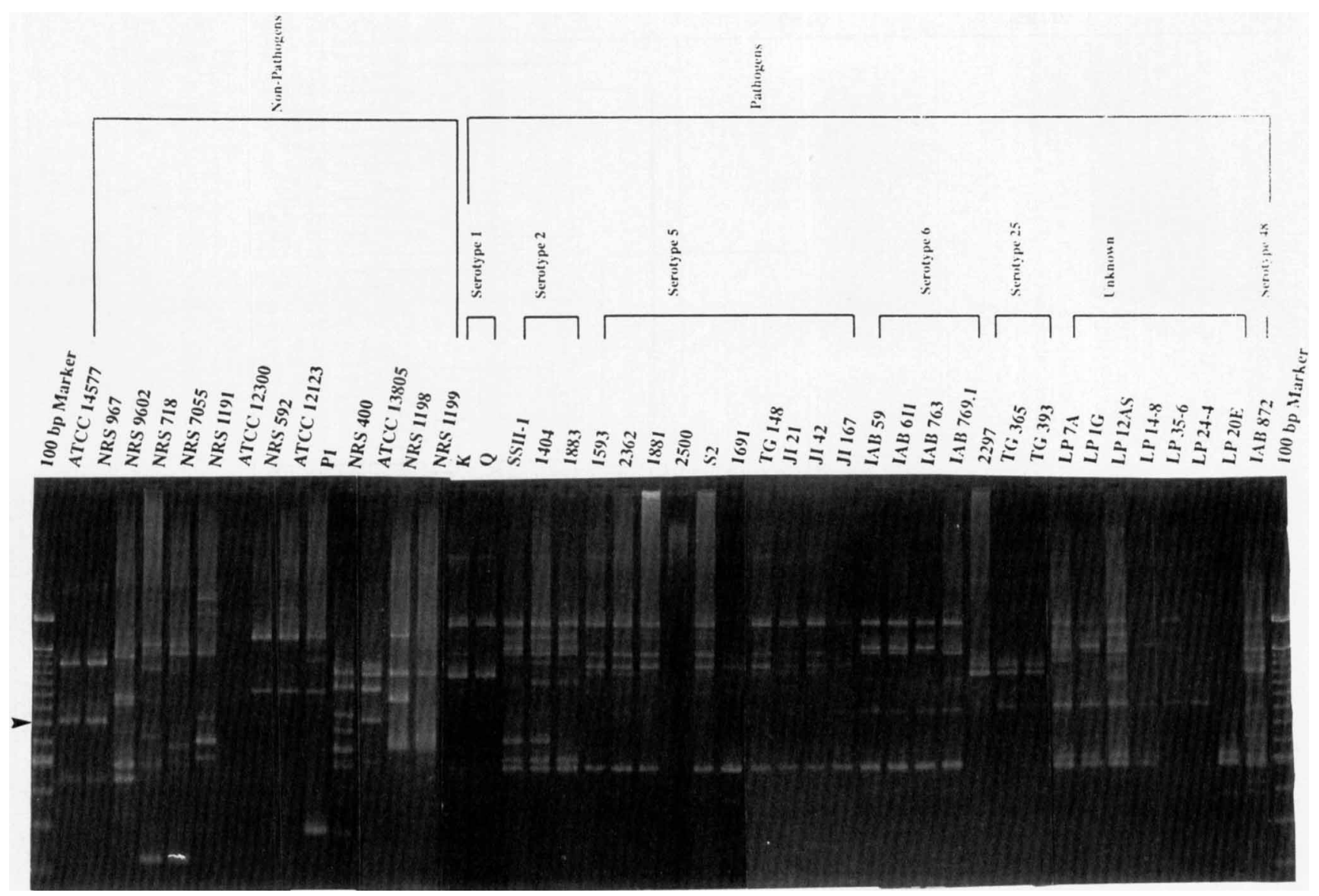

FIG. 3. RAPD band patterns generated by using primer OPA-7 and template DNAs from pathogenic and nonpathogenic members of the homology groups. The serotypes within DNA homology group IIA are indicated at the top. 100 bp Marker, DNA ladder with 100-bp increments (the arrowhead indicates the band at 800 bp).

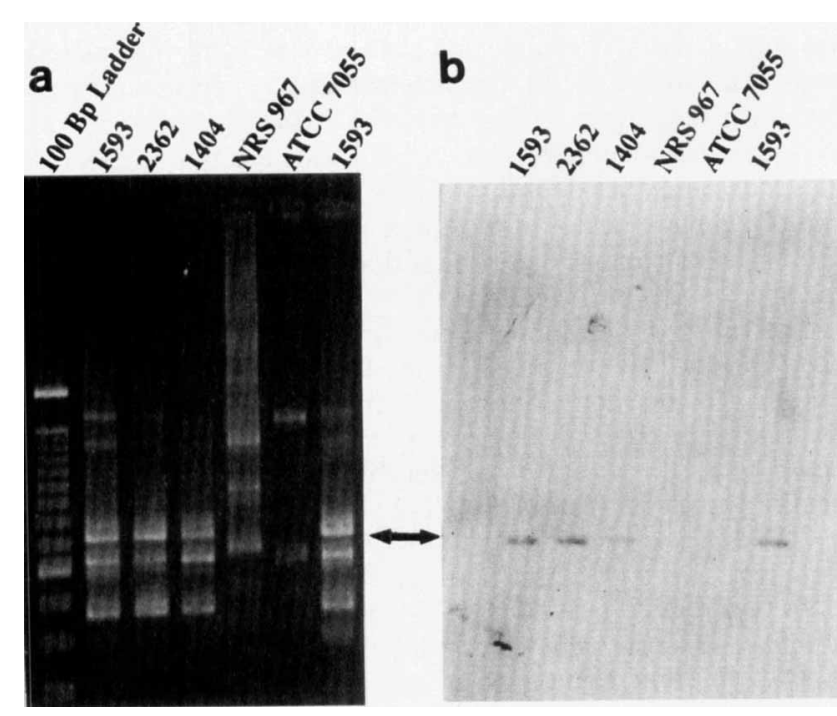

FIG. 4. (A) RAPD band patterns generated by using primer OPB-18. $100 \mathrm{Bp}$ Ladder, DNA ladder with 100-bp increments (the arrow indicates the band at $800 \mathrm{bp}$ ). (B) Southern blot of the gel in panel A hybridized with digoxigeninlabeled probe prepared from the 725-bp strain 1593 DNA fragment (indicated by the arrow).
OPA-17 was allowed to hybridize with plasmid preparations from four pathogenic strains, 1404, 2362, 1593, and 2297. The largest of these plasmids was approximately $180 \mathrm{~kb}$ long, and the smallest was 4.9 to $5.3 \mathrm{~kb}$ long. These plasmid preparations and a RAPD amplification product from strain 1593 were electrophoresed, transferred, and allowed to hybridize with the probe. Hybridization occurred only with the RAPD products and not with plasmids (data not shown).

RAPD band analysis. We observed a total of 265 bands in the analysis in which we used eight primers and 45 strains. The results obtained when we calculated similarity coefficients by the method of Jaccard and clustered the data by the UPGMA are shown as a dendrogram in Fig. 5. The coefficient of correlation between the UPGMA clustering data and the similarity matrix data was 0.994. On this dendrogram, the DNA homology groups and the serotypes within homology group IIA were readily distinguished. The average levels of similarity between nonpathogenic homology groups ranged from 5 to $10 \%$, and these homology groups exhibited 5.2 to $7.1 \%$ similarity to homology group IIA. The level of similarity for DNA homology groups IIA and IIB was 5.2\%. Within each group IIA serotype there was at least $84 \%$ similarity between all strains except strain 2500 . The majority of the group IIA strains clustered at a similarity level of $70 \%$. The remaining DNA homology groups were more heterogeneous. The group 1 strains clustered at a similarity level of $40 \%$, the group IIB strains clustered at a similarity level of $15 \%$, the group III and IV strains 


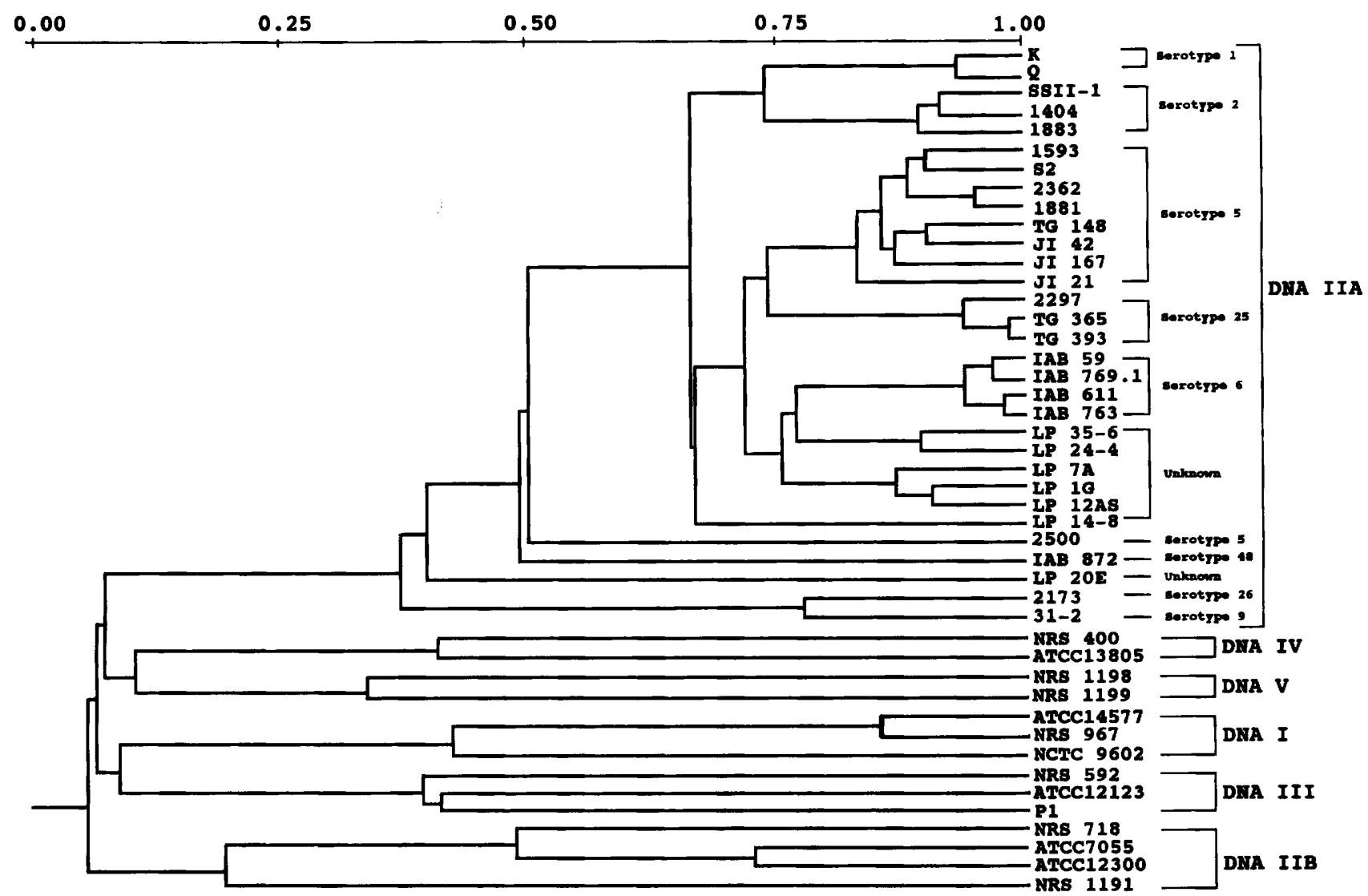

FIG. 5. UPGMA dendrogram derived from similarity coefficients calculated by the Jaccard method, showing the relationships among $B$. sphaericus strains.

clustered at a similarity level of $37 \%$, and the group V strains clustered at a similarity level of $30 \%$.

\section{DISCUSSION}

The bacteria which form round spores and are presently included in the species $B$. sphaericus have been shown to belong to at least five distinct DNA homology groups (14). These results, which have been supported by the results of an rRNA sequence analysis (3), a fatty acid analysis (12), and a numerical analysis based on over 100 phenotypic tests (1), were supported by RAPD fingerprinting results in this study.

Although the mosquito pathogens belonging to homology group IIA exhibit 57 to $64 \%$ homology with the nonpathogenic group IIB reference strain (14), the results of our RAPD analysis indicated that the group IIA strains were not more similar to the group IIB strains than they were to the strains belonging to any other homology group. Alexander and Priest (1) were able to distinguish the group IIA pathogens from the group IIB nonpathogens by the ability of the pathogens to clear adenine from nutrient agar. An additional unique trait is pathogenicity, which is based on the production of one or both of the toxins. Previously, toxin production could be demonstrated only by an assay in which mosquito larvae were used, but now because probes based on 16S rRNA sequences (3) or on the toxins themselves (4) are available, it is possible to identify group IIA strains more directly.

The possibility that of the mosquito pathogens should be described as a new species can be compared with the situation found with the insect pathogen $B$. thuringiensis. In this case the species is based on the production of a parasporal body at the time of sporulation. In most (but not all) cases, this parasporal body contains proteins that are toxic to a variety of insects. The existence of $B$. thuringiensis as a species separate from Bacillus cereus has been questioned $(5,8,17)$. The results of previous studies and the fact that the $B$. thuringiensis parasporal proteins are encoded on plasmids that can be lost from the bacteria require balancing the practical uses of species designation with the logic flowing from the research data. The toxins of the mosquito-pathogenic $B$. sphaericus strains are not encoded on plasmids, and this defining trait is stable. Thus, the case for creating a new species of mosquito pathogens that form round spores is as strong as or stronger than the case for maintaining the species $B$. thuringiensis.

The reliability of comigrating bands in RAPD analyses has been questioned. In this RAPD study, the amplified DNAs produced with each primer that migrated the same distance were considered equivalent when we calculated similarity values. This assumption was verified by labeling all of the amplification products from a RAPD reaction, as well as one isolated DNA fragment from another reaction. When the probes were hybridized with bands produced by using template DNAs from two related strains (strains belonging to the same DNA homology group) and two unrelated strains (strains belonging to two different homology groups), the probes reacted only with the homologous bands. This indicates that the bands that migrated the same distance were probably amplified from the same segment of DNA.

The ability of RAPD fingerprinting data to place most of the mosquito pathogens into the correct serotypes was of consid- 
erable interest. The correlation of RAPD data with serotype, bacteriophage type, and the type of toxin (binary or $100 \mathrm{kDa}$ ) produced by the bacteria indicates that the origins of the bacteria belonging to each serotype were clonal. The RAPD results demonstrated that the groups defined by flagellum antigenicity have broader genetic similarities, which were reflected in the binding patterns of the primers used in this study. The bacterial isolates belonging to each serotype originated in many parts of the world, but within each serotype the bacteria appear to have uniform characteristics. There is no evidence that genetic information has been exchanged among the groups, as has been found in $B$. thuringiensis, in which a variety of different toxin combinations can be found within any one serotype.

The LP strains, which were isolated in Singapore, are the only strains among the pathogens that are known to produce only the binary toxin and not the $100-\mathrm{kDa}$ toxin. The results of the RAPD analysis grouped these strains together and suggested that they may constitute a new serotype that is most similar to serotype 6 (level of similarity, 75\%). Strain LP 20E fell outside the group, and its position will be determined only when the entire group is serotyped.

Amplification of DNA segments located on plasmids could confuse RAPD analyses since plasmids may be unstable and be lost from bacteria. This could change band patterns. Pathogenic strain 1593 and many other pathogens carry a large cryptic plasmid that is approximately $180 \mathrm{~kb}$ long. To rule out the possibility that this plasmid contributes amplification products, a labeled probe prepared from strain 1593 amplified template DNA was hybridized to blots on a plasmid gel prepared from four pathogenic strains, as well as to a blot of a RAPD product from strain 1593 . The probe hybridized only with the RAPD products and not with the plasmids. This indicates that at least with this primer and in these strains, plasmids do not contribute to the band patterns.

The results of RAPD fingerprinting support the results of previous DNA homology and related studies which indicated that there is heterogeneity within the species B. sphaericus. Species status for the mosquito pathogens appears to be justified on the basis of the data that have been obtained. The data also suggest that the origin of the various serotypes was clonal.

\section{ACKNOWLEDGMENT}

This research was supported by cooperative research agreement CR819744-01 from the Environmental Research Laboratory, U.S. Environmental Protection Agency, Duluth, Minn.

\section{REFERENCES}

1. Alexander, B., and F. G. Priest. 1990. Numerical classification and identification of Bacillus sphaericus including some strains pathogenic for mosquito larvae. J. Gen. Microbiol. 136:367-376.
2. Aquino de Muro, M., W. J. Mitchell, and F. G. Priest. 1992. Differentiation of mosquito-pathogenic strains of Bacillus sphaericus from non-toxic varieties by ribosomal RNA gene restriction patterns. J. Gen. Microbiol. 138: 1159-1166.

3. Aquino de Muro, M., and F. G. Priest. 1993. Phylogenetic analysis of Bacillus sphaericus and development of an oligonucleotide probe specific for mosquito-pathogenic strains. FEMS Microbiol. Lett. 112:205-210.

4. Aquino de Muro, M., and F. G. Priest. 1994. A colony hybridization procedure for the identification of mosquitocidal strains of Bacillus sphaericus on isolation plates. J. Invertebr. Pathol. 63:310-313.

5. Baumann, L., K. Okamoto, B. Unterman, M. Lynch, and P. Baumann. 1984. Phenotypic characterization of Bacillus thuringiensis and Bacillus cereus. J. Invertebr. Pathol. 44:329-341.

6. Baumann, P., M. A. Clark, L. Baumann, and A. H. Broadwell. 1991. Bacillus sphaericus as a mosquito pathogen: properties of the organism and its toxins. Microbiol. Rev. 55:425-436.

7. Brousseau, R., A. Saint-Onge, G. Prefontaine, L. Masson, and J. Cabana. 1993. Arbitrary primer polymerase chain reaction, a powerful method to identify Bacillus thuringiensis serovars and strains. Appl. Environ. Microbiol. 59:114-119.

7a.Burke, W. F. Personal communication.

8. Carlson, C. R., D. Caugant, and A.-B. Kolst. 1994. Genotypic diversity among Bacillus cereus and Bacillus thuringiensis strains. Appl. Environ. Microbiol. 60:1719-1725.

9. de Barjac, H., I. Larget-Thiery, V. C. Dumanoir, and H. Ripouteau. 1985. Serological classification of Bacillus sphaericus strains on the basis of toxicity to mosquito larvae. Appl. Microbiol. Biotechnol. 21:85-90.

10. Ellsworth, D. L., K. D. Rittenhouse, and R. L. Honeycutt. 1993. Artifactual variation in randomly amplified polymorphic DNA banding patterns. BioTechniques 14:214-217.

11. Emanuel, J. R. 1991. Simple and efficient system for synthesis of nonradioactive nucleic acid probes using PCR. Nucleic Acids Res. 19:2790.

12. Frachon, E., S. Hamon, L. Nicholas, and H. de Barjac. 1991. Cellular fatty acid analysis as a potential tool for predicting mosquitocidal activity of Bacillus sphaericus strains. Appl. Environ. Microbiol. 57:3394-3398.

13. Johnson, J. L. 1973. Use of nucleic-acid homologies in the taxonomy of anaerobic bacteria. Int. J. Syst. Bacteriol. 23:308-315.

14. Krych, V. K., J. L. Johnson, and A. A. Yousten. 1980. Deoxyribonucleic acid homologies among strains of Bacillus sphaericus. Int. J. Syst. Bacteriol. 30: $476-484$.

15. Lion, T., and O. A. Hass. 1990. Nonradioactive labeling of probe with digoxigenin by polymerase chain reaction. Anal. Biochem. 188:335-337.

16. Meunier, J.-R., and P. A. D. Grimont. 1993. Factors affecting reproducibility of random amplified polymorphic DNA fingerprinting. Res. Microbiol. 144: 373-379.

17. Nakamura, L. 1994. DNA relatedness among Bacillus thuringiensis serovars. Int. J. Syst. Bacteriol. 44:125-129.

18. Park, Y.-H., and R. J. Kohel. 1994. Effect of $\mathrm{MgCl}_{2}$ concentration on random-amplified DNA polymorphism. BioTechniques 16:652-656.

19. Porter, A. G., E. W. Davidson, and J.-W. Liu. 1993. Mosquitocidal toxins of bacilli and their genetic manipulation for effective biological control of mosquitoes. Microbiol. Rev. 57:838-861.

20. Priest, F. G., D. A. Kaji, and M. Aquino de Muro. Systematics of insect pathogenic bacilli: uses in strain identification and isolation of novel pathogens. Submitted for publication.

21. Rohlf, F. J. 1994. NTSYS-pc numerical taxonomy and multivariant analysis system, version 1.80. Exeter Publishing, Ltd., Setauket, N.Y.

22. Welsh, J., and M. McClelland. 1990. Fingerprinting genomes using PCR with arbitrary primers. Nucleic Acids Res. 18:7213-7218.

23. Williams, J. G. K., A. R. Kubelik, K. J. Livak, J. A. Rafalski, and S. V. Tingey. 1990. DNA polymorphisms amplified by arbitrary primers are useful as genetic markers. Nucleic Acids Res. 18:6531-6535.

24. Yousten, A. A. 1984. Bacteriophage typing of mosquito pathogenic strains of Bacillus sphaericus. J. Invertebr. Pathol. 43:124-125. 